\title{
Geology, Mineralogy and Geochemistry of the Oligocene Oolitic Iron Ore of the Continental Terminal Formation, Kandi Basin, North-East Benin
}

\author{
Adiss Kamal Issifou Fatiou1,2*, Moussa Konaté1, Soulémana Yessoufou' ${ }^{2}$, \\ Cossi Luc Adissin Glodji², Matthias Heckmann ${ }^{3}$, Hamidou Garba Saley ${ }^{1}$
}

${ }^{1}$ Department of Geology, Groundwater and Georesources Laboratory, Faculty of Sciences and Technology, Abdou Moumouni University of Niamey, Niamey, Niger

${ }^{2}$ Department of Earth Sciences, Laboratory of Geology, Mines and Environment, Faculty of Sciences and Technology, University of Abomey-Calavi, Abomey-Calavi, Benin

${ }^{3}$ Federal Institute for Geosciences and Natural Resources (BGR), Hannover, Germany

Email: *kamdisse@gmail.com

How to cite this paper: Fatiou, A.K.I., Konaté, M., Yessoufou, S., Glodji, C.L.A., Heckmann, M. and Saley, H.G. (2019) Geology, Mineralogy and Geochemistry of the Oligocene Oolitic Iron Ore of the Continental Terminal Formation, Kandi Basin, North-East Benin. International Journal of Geosciences, 10, 491-512. https://doi.org/10.4236/ijg.2019.104029

Received: March 3, 2019

Accepted: April 27, 2019

Published: April 30, 2019

Copyright $\odot 2019$ by author(s) and Scientific Research Publishing Inc. This work is licensed under the Creative Commons Attribution International License (CC BY 4.0).

http://creativecommons.org/licenses/by/4.0/

c) (i) Open Access

\begin{abstract}
The Oligocene Continental Terminal Formation of the Kandi Basin contains high grades of iron mineralization ( $56.72 \%$ Total $\mathrm{Fe})$. The microscopic study under the polarized and reflected light showed that the iron ore consists of silicate minerals (quartz 50\% and zircon 1\%) and non-silicate minerals (goethite $30 \%$, hematite $7 \%$, magnetite $3 \%$, pyrite $1 \%$, chalcopyrite $1 \%$, blende $3 \%$, galena $3 \%$, scheelite $1 \%$ and gold $2 \%$ ). The X-rays fluorescence shows that the iron ore is characterized by various elements, such as $\mathrm{Fe}_{2} \mathrm{O}_{3}$ (57.91\% to $91.33 \%$ ), $\mathrm{SiO}_{2}$ (3.07\% to $33.19 \%$ ), aluminum (2.94\% to $7.74 \%$ ), vanadium $(0.04 \%$ to $0.11 \%)$, phosphorus $(0.79 \%$ to $2.29 \%)$ and sulfur $(<0.3 \%)$. The deleterious elements grade is above the permissible limit in metallurgy $(0.05 \%-0.07 \%$ for phosphorus and $0.1 \%$ for sulfur). Their high grades indicate that the Kandi Basin iron ore characteristics are not favorable for steel manufacturing despite its good vanadium contents ( $0.04 \%$ to $0.11 \%)$. However, it could be used for the cast iron manufacture. Spectrometric analysis by atomic absorption confirms the presence of low-grade gold associated to the iron ore (from 0.006 to $0.015 \mathrm{ppm}$ ). The comparative study of discontinuous stratiform iron ore of the Kandi Basin with other oolitic iron ores in exploitation from other countries such as Brazil, Australia, China, Russia, Uganda and the United States shows that iron ore of the Kandi Basin can be mined despite its high silica content.
\end{abstract}




\section{Keywords}

Kandi Basin, Oolitic Iron Ore, Continental Terminal Formation

\section{Introduction}

The ore classification takes into account several parameters such as grade, quantity, nature and shape. Each parameter corresponds to an important technical criterion taken into account for the evaluation of the economic potential of the ores.

Iron ore is among the most mined in the world, with a production of 1.9 billion tonnes per year [1]. The quality of iron ore is mainly determined by its chemical composition [2]. The main minerals from which iron is extracted are: hematite $\mathrm{Fe}_{2} \mathrm{O}_{3}(70 \% \mathrm{Fe})$, magnetite $\mathrm{Fe}_{3} \mathrm{O}_{4}(72 \% \mathrm{Fe})$ and rarely limonite $2 \mathrm{Fe}_{2} \mathrm{O}_{3} \cdot 3 \mathrm{H}_{2} \mathrm{O}(60 \% \mathrm{Fe})$, siderite $\mathrm{FeCO}_{3}(48.3 \% \mathrm{Fe})$ and pyrite $\mathrm{FeS}_{2}(46.6 \% \mathrm{Fe})[2]$.

Mined since prehistoric times, oolitic iron ores are important sources of iron [3]. This metal represents for human being the most important element among all elements of the periodic classification of Mendeleiev [4].

Oolitic iron ores of continental origin are exploited as those of marine origin [5]. Of all the 175 known oolitic iron ores in the world, only a few have undergone detailed mineralogical and geochemical analysis [6] [7].

Very few studies have been conducted on oolitic iron ores in West Africa [7]. These iron ores are particularly abundant in the formation of the Continental Terminal of Iullemmeden basin. They have many levels of high iron content that can be mined economically [8] [9].

In northeastern Benin and southwestern Niger (Figure 1), the Kandi Basin contains the most high graded iron ore of Benin Republic with estimated reserves of more than 300 million tonnes [10]. Known incorrectly as the "iron deposit" of the Kandi Basin [11], iron ore is especially important in the Continental Terminal Formation. It has been mined traditionally for more than a century [12]. This formation, Oligocene in age [13], forms a subhorizontal sedimentary layer ranging from massive and oolitic goethite to ferruginous sandstones [14]. It is a large detrital spread with ferruginous concretion and kaolinite [15]. Iron ore extends over thousands of $\mathrm{km}^{2}$ in northwestern Nigeria and northeastern Benin [14] [16].

The Kandi Basin iron ore has not received adequate attention in terms of mineralogical, metallurgical and geochemical studies. Most of the executed exploration surveys are preliminary and engaged in the reserves assessment of the iron ore, hence, the necessity of the current work.

The aim of this preliminary survey is to improve the geological knowledge of the oolitic iron ore of the Continental Terminal Formation. More specifically, the objectives deal to determine the mineralogical, geochemical and metallurgical characteristics of iron ore in the Madékali-Loumbou-Loumbou areas. 


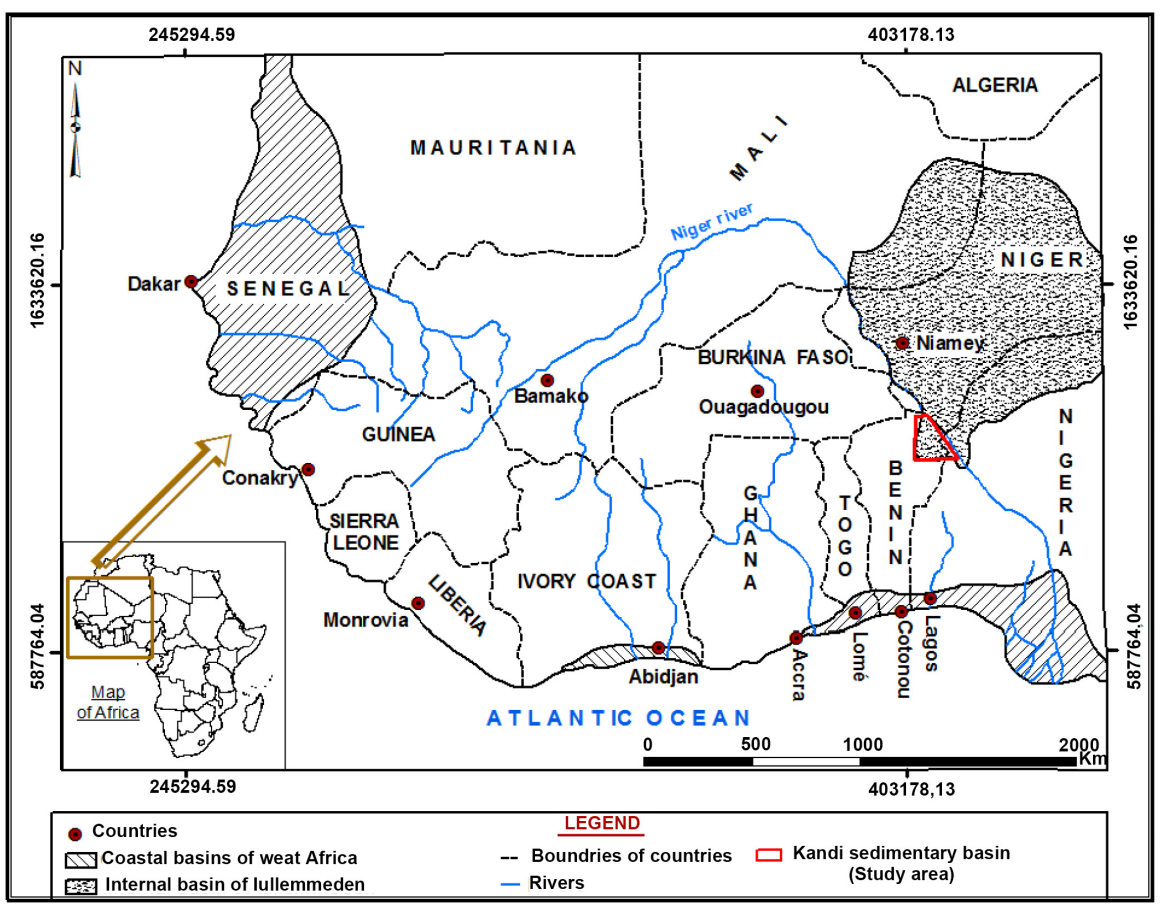

Figure 1. Geographical location of the study area in west Africa (Source: [28]; modified).

\section{Geological Setting}

The sedimentary series of the Kandi Basin overlie the Pan-African basement separated by a major unconformity through a basal conglomerate or conglomeratic coarse sandstone [14]. The formations in the study area consist of dominant terrigenous sandstone rocks including from the bottom to the top (Figure 2), the lower Paleozoic deposits overlain in the Sendé sector by Cretaceous deposits on which overlie through an erosional unconformity the Continental Terminal sediments presumed Oligocene in age [13]. The Lower Paleozoic detrital series begins with the Wéré fluvio-glacial formation. The latter is spatially restricted to the fault-bounded paleovalley, marking the western edge of the Kandi Basin. About 500 meters in thickness [17], the sedimentary infilling of the fault-bounded paleovalley consists of conglomerate and polygenic breccia with large boulders scattered in a sandy-argillaceous ferrugineous matrix. These conglomeratic deposits move towards the northeastern (sectors of Goungoun and Guéné) to polygenic breccias of clast-supported to matrix-supported type [18]. Wéré upper sandstone deposits are vertically and laterally relayed by tidal to subtidal deposits of the Late Ordovician - Lower Silurian Kandi Formation [19].

The Kandi Formation (Figure 2), with about $80 \mathrm{~m}$ in thickness, consists of an alternation of sandstone and clayey-siltstone [17]. This Kandi Formation is overlain by coarse sandstone deposits with subordinate silts and clays of the lower Cretaceous continental formation of Sendé. The latter is separated from Kandi's one by a ravinement surface [14]. Sendé's Formation is overlain by the Continental Terminal Formation which is dominated at the bottom by a kaolinic 


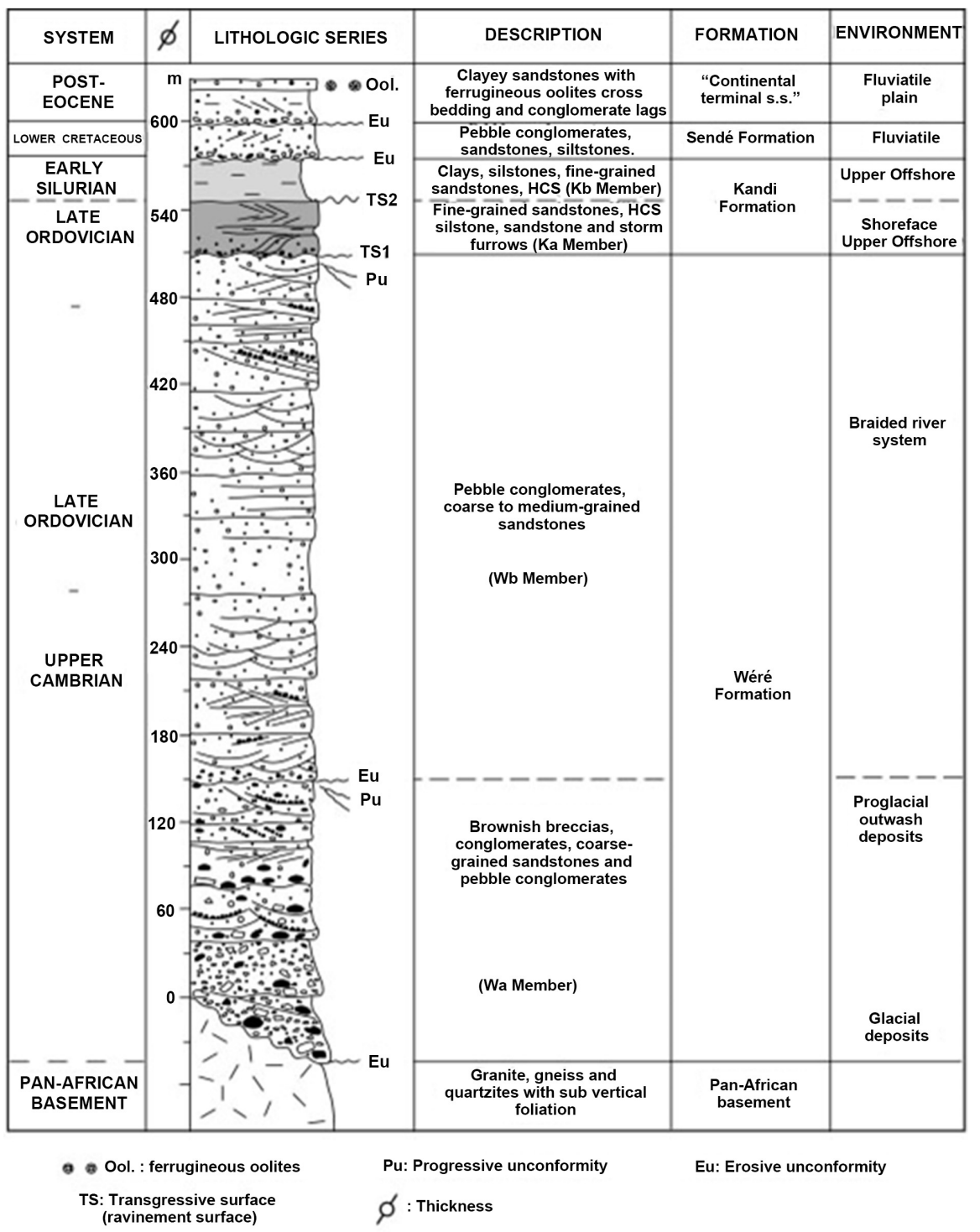

Figure 2. Lithostratigraphic log of the Kandi sedimentary basin showing the oolitic iron ore at the top (Source: [19]).

clay, microconglomeratic sandstone and at the top by an oolitic ferruginous sandstone. Quaternary formations are poorly developed in the Kandi Basin. They are found on the banks of the river of Niger, Sota and Alibori (Figure 3). They consist of quartzitic sandstones and clays [14].

The Kandi major fault $\mathrm{N} 20^{\circ}$ trending, controls the west-to-east spatial distribution of alluvial, fluvial and marine detritic facies and the sedimentary geometry structured in a synclinal half-graben shape [17].

\section{Material and Methods}

The methodology of this study includes four main steps:

1) The first step focus on the description of the outcroping rocks in the study area and the realizing of structural cross-sections. 


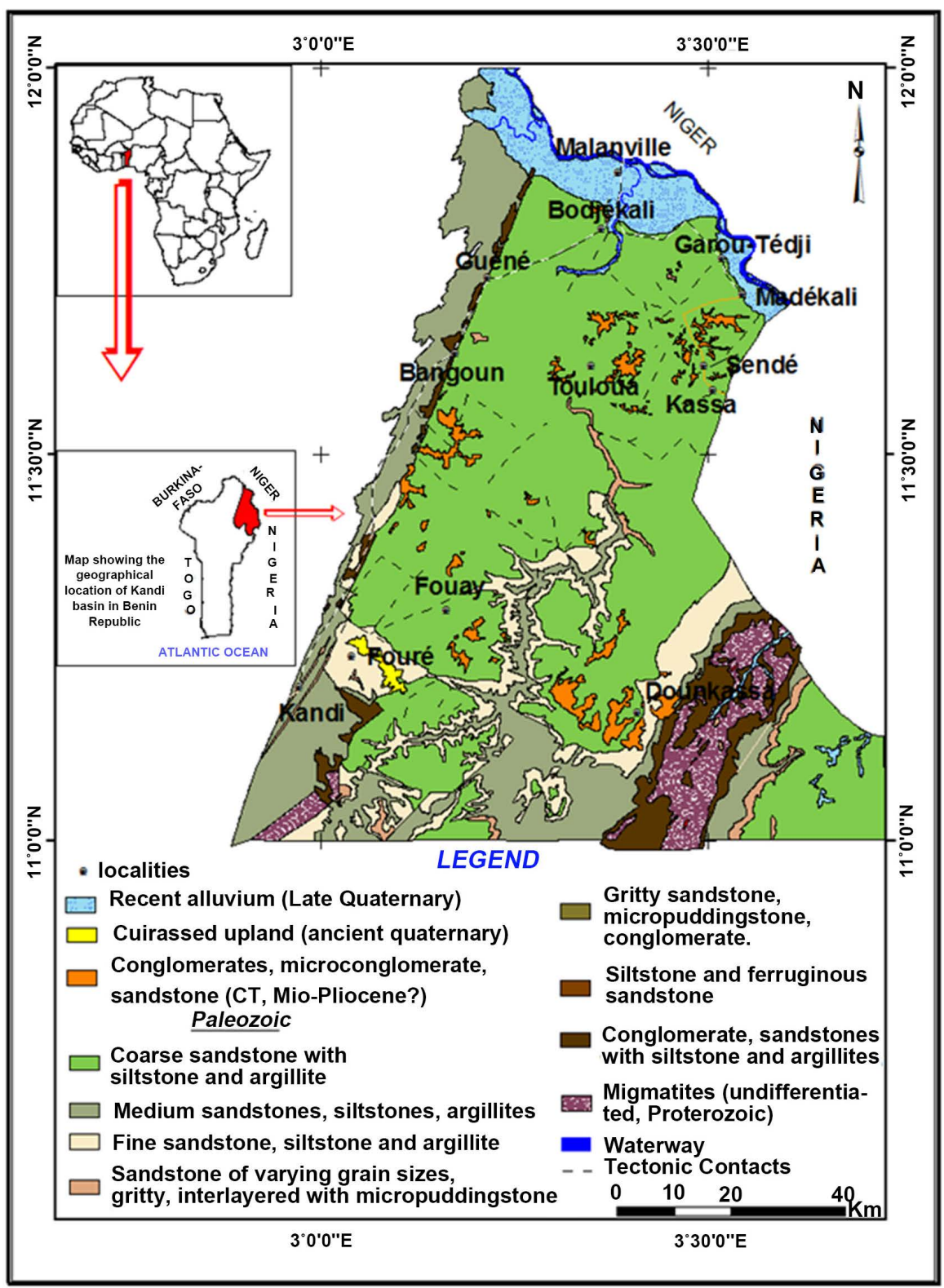

Figure 3. Geological map of the study area (source [28]).

2) The second stage consists of analyzing and measurements of the sedimentary and tectonic structures. During this step, a total of 150 iron ore samples were collected and 60 of them were subjected to laboratory analysis.

3) The third step involves laboratory works which consisted of microscopic study (30 thin sections in transmitted light and 10 polished sections in reflected light) and geochemical analysis (10 samples by X-ray fluorescence at Activation Laboratory Ontario in Canada and the other 10 samples by Atomic Absorption Spectrometry at Actlabs Ouagadougou in Burkina Faso).

4) In the fourth step, the interpretation of petrographic, mineralogical and geochemical data were carried out. The geochemical data were used to determine the relationships between the main interest oxide $\left(\mathrm{Fe}_{2} \mathrm{O}_{3}\right)$ and the 
other oxides. It is based on the use of MINITAB 14 software which also allows statistical analysis. Regression with "fitted line plot" has been adopted to understand the different relationships that exist between elements.

\section{Results}

\subsection{Field Observations}

The oolitic iron ore of the Kandi Basin corresponds to the upper level of the undifferentiated Continental Terminal Formation (Figure 3). It is commonly characterized by the presence of three types of faciological elements such as, a kaolinic layer at the bottom, scattered termitic traces and ferrugineous oolite and pisolite layers at the top. This Continental Terminal Formation is composed of four sedimentary levels. The basal level, about $1 \mathrm{~m}$ in thickness consists of microconglomeratic ferrugineous coarse-grained sandstone with unclear cross bedding. It is overlain by a second whitish sandstone level with kaolinic cement gradually moving to variegated kaolin. The third level corresponds to reddish clayey sandstones, about 8 meters in thickness. It is relayed vertically by ferrugineous oolitic horizontal sandstone hosting the iron ore. The ferrugineous mineralization levels are about three meters in thickness. They are often capped by a ferrugineous pisolitic concretion, about $5 \mathrm{~m}$ in thickness (Figure 4).

The iron ore is affected by several fractures of many trends. Three types of sub-facies characterize the iron ore: the first one is sandy, ferrugineous, oolitic and horizontal (Figure 4 and Figure 5), the second exibits ferrugineous pisolitic concretions (Figure 6) and finally the third type is poorly sorted deposit due to the posterior remobilization of oolitic ferrugineous sandstones pebbles (Figure 7).

\subsection{Mineralogical Composition of the Kandi Basin Iron Ore}

Detailed petrographic analyses allow us to classify the mineralogical composition into silicate minerals and non-silicate minerals (iron oxides and hydroxides, sulphides and native elements).

\subsubsection{Under the Polarizing Microscope}

In polarized light, non-silicate minerals are characterized by an opacity due to their isotropy. They have a brownish or sometimes blackish color forming mainly the cortex of oolites and pisolites (Figure 8). The silicate minerals are represented by the xenomorphic quartz having a textural variety and an angular to sub-angular shape, suggesting a proximal origin (Figure 9). Incidentally, we find crystals of zircons (Figure 10) and scheelite (Figure 11).

The zircon crystals are hexagonal in shape and have black aureoles.

\subsubsection{Under the Metallographic Microscope}

Under the metallographic microscope, the opaque minerals correspond to iron oxides and hydroxides, sulphides and native elements. Oxides and hydroxides 


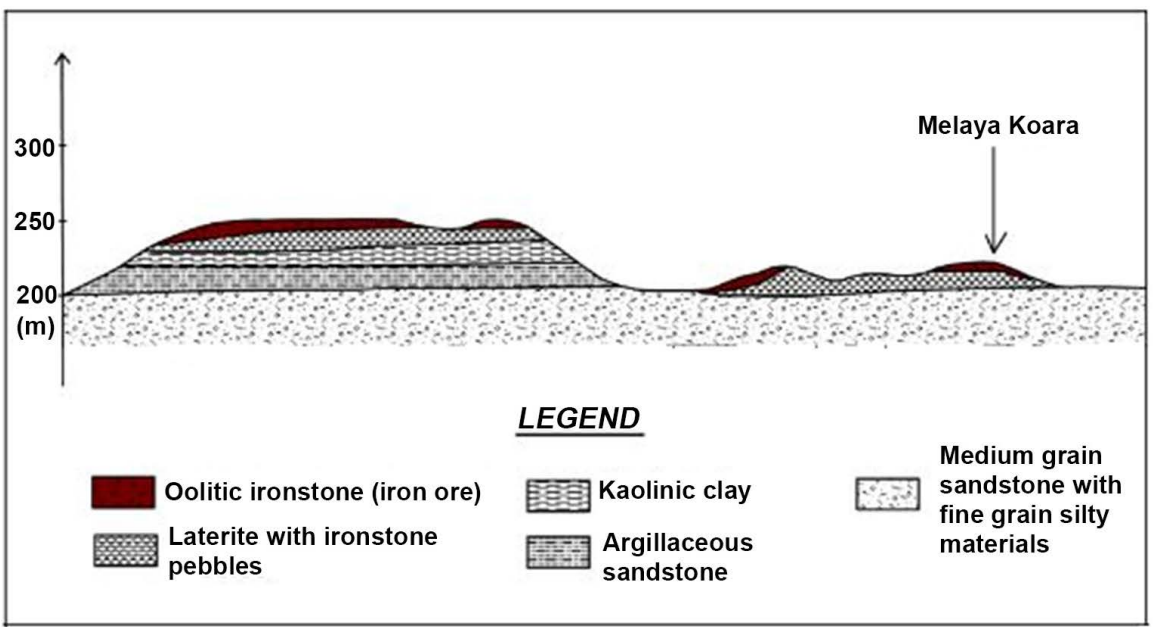

Figure 4. Cross section of the Tourougo area showing the vertical succession of the Continental Terminal deposits. The uppermost deposits include the oolitic iron mineralisation (Location in Figure 2).

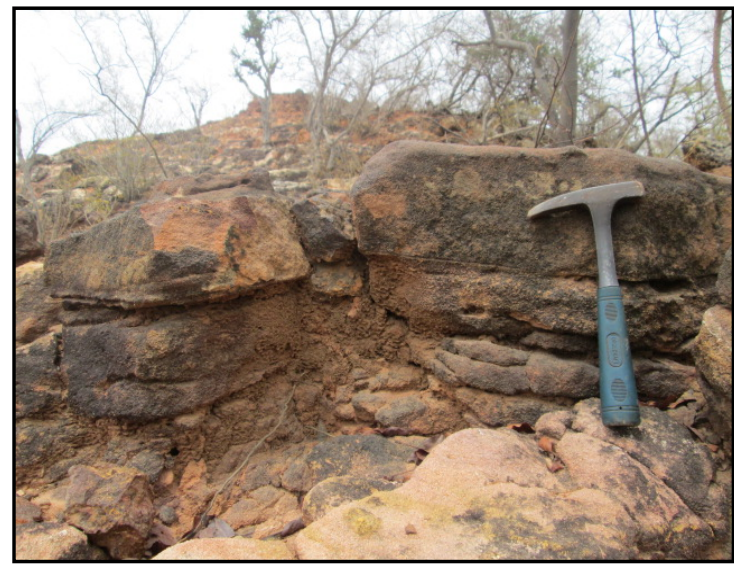

Figure 5. Ferrugineous sandstone of the Continental Terminal hosting the iron ore deposit (Madekali area, northeastern part of Kandi Basin).

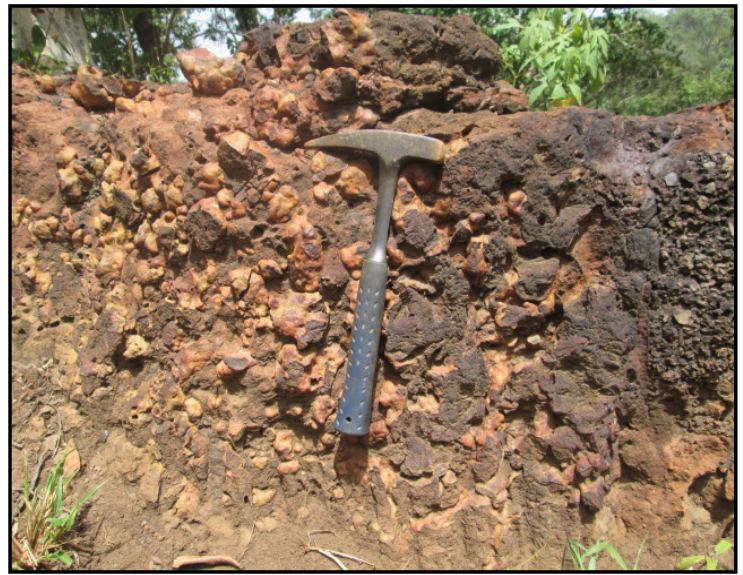

Figure 6. Ferruginous concretion (southern part of Kandi Basin, Goungoun sector). 


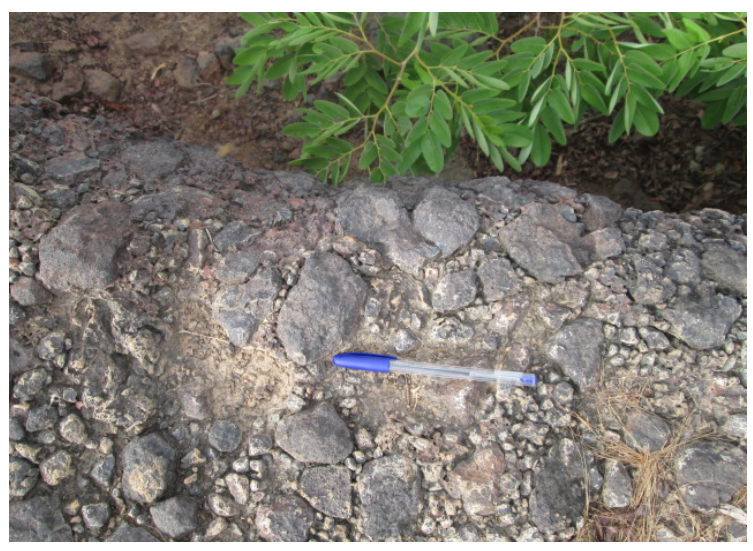

Figure 7. Field observation showing conglomeratic sandstone with ferrugineous rounded clast supported facies and nearly matrix supported facies. These deposits are related to a reworked facies (Madekali sector, northeastern part of Kandi Basin).

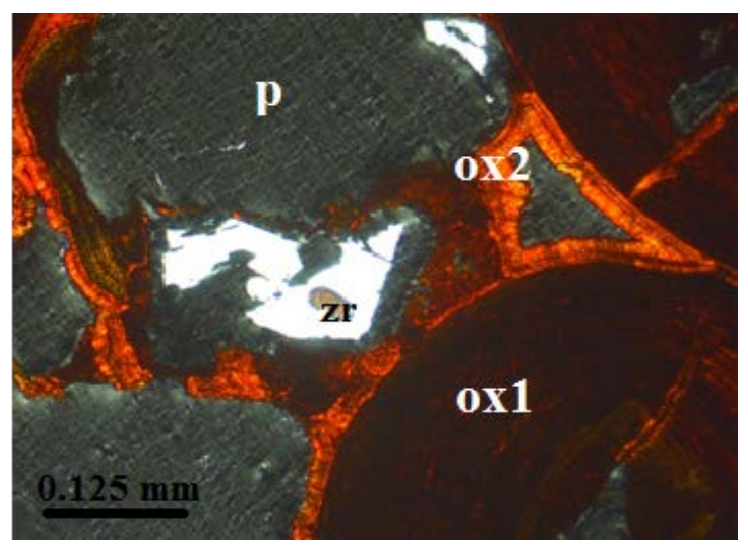

Figure 8. Photo micrograph showing the oxides and hydroxides seen under the polarizing microscope (Ox1: oxides and hydroxides forming mostly oolites and pisolites cortex, Ox2: oxides and hydroxides forming mostly the binding agent, P: pores, Zr: zircon).

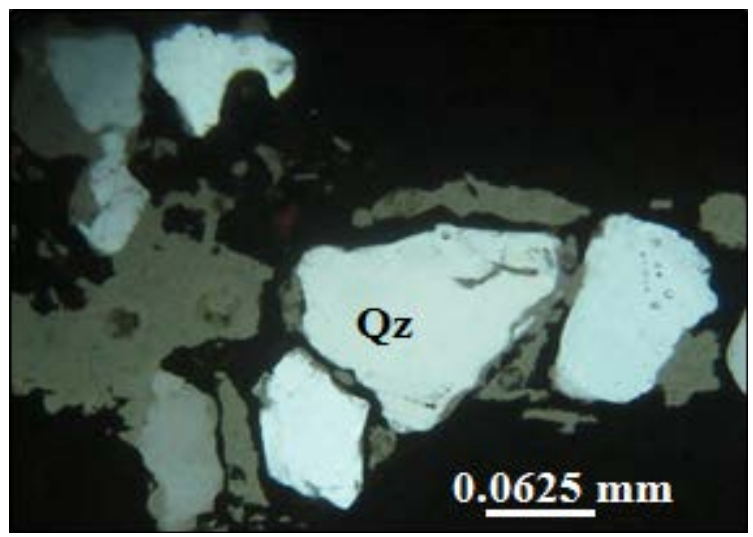

Figure 9. Photo micrograph showing the shape of quartz under the polarizing microscope (Qz: quartz). 


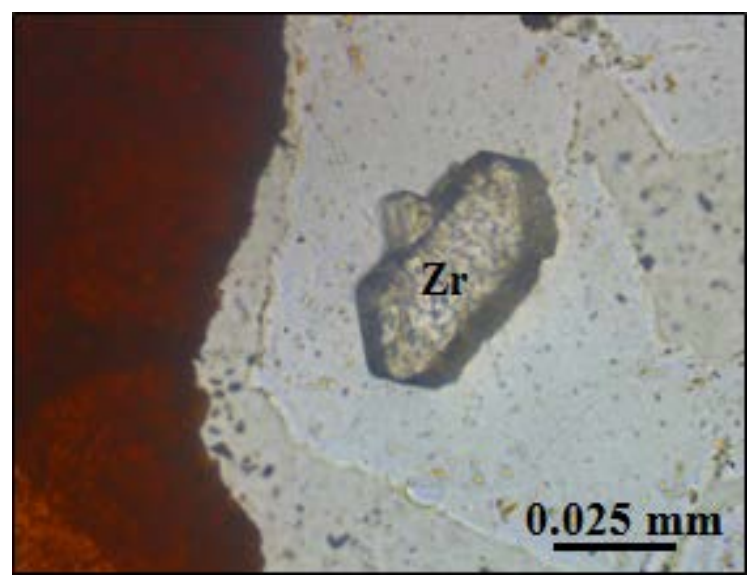

Figure 10. Photo micrograph showing detrital zircon under the polarizing microscope (Zr: zircon).

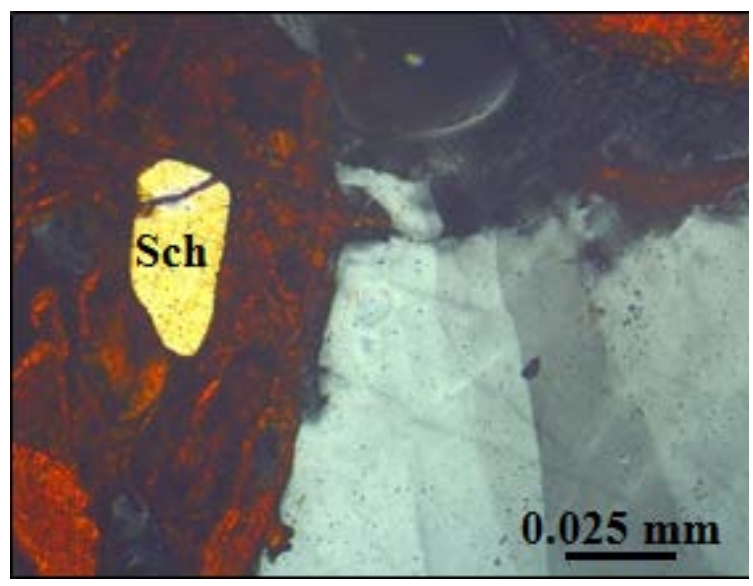

Figure 11. Photo micrograph showing the scheelite highlighted in ferruginous sandstones, under the polarizing microscope (Sch: scheelite).

are represented in decreasing proportion by goethite, hematite and magnetite (Figure 12). Goethite is characterized by its dark color sometimes brownish. The transition from black to brownish color marks the transformation of goethite into hematite under the effect of dehydration [2]. This transformation is expressed by the below equation:

$$
2 \mathrm{FeOOH} \rightarrow \mathrm{Fe}_{2} \mathrm{O}_{3}+\mathrm{H}_{2} \mathrm{O}
$$

The sulphides are here represented by Galena, blende, pyrite and finally chalcopyrite (Figure 13).

The only native element, highlighted by the present study, is xenomorphic gold $(\mathrm{Au})$, occupying the intergranular spaces of ferruginous sandstones (Figure $14)$.

Iron ore from the Kandi Basin is composed of silicate minerals (silica $37 \%$ and zircon $1 \%$ ) and non-silicate minerals (goethite $40 \%$, hematite $10 \%$, magnetite $3 \%$, pyrite $2 \%$, chalcopyrite $1 \%$, blende $3 \%$, galena $3 \%$ and gold $2 \%$ ). 


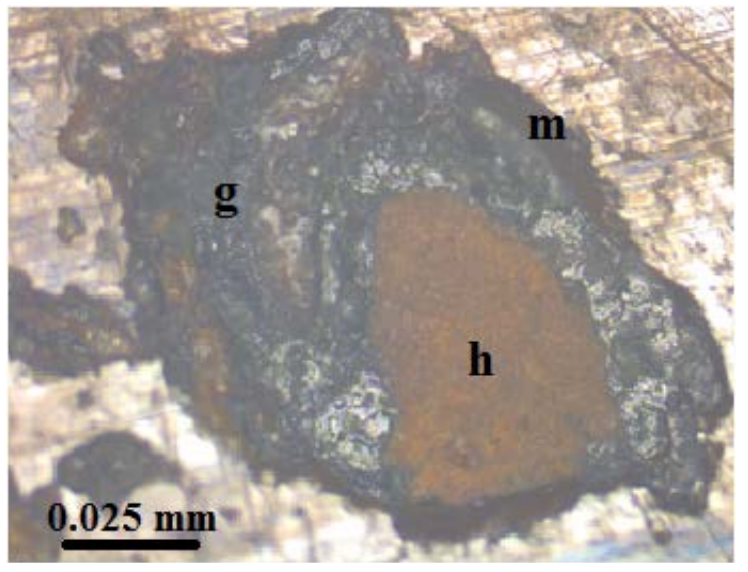

Figure 12. Photo micrograph showing different oxides and hydroxides observed in polished section (g: goethite, h: hematite, m: magnetite).

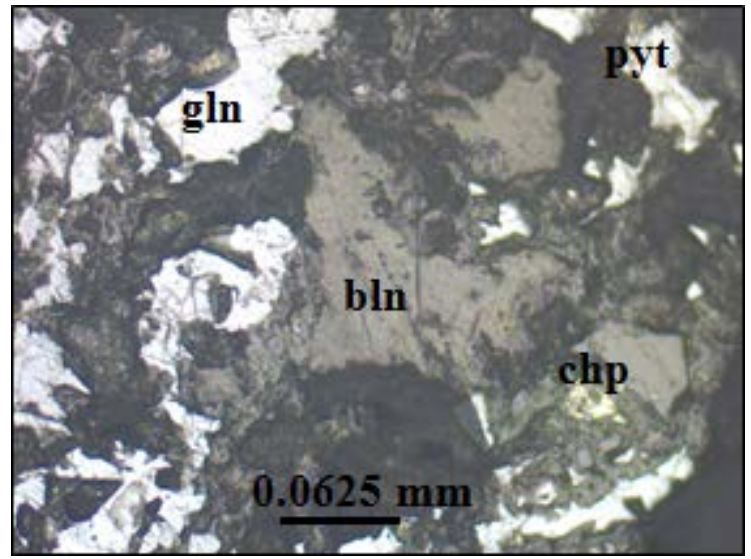

Figure 13. Photo micrograph showing different sulphides observed in polished section (gln: galena, bln: blende, pyt: pyrite, chp: chalcopyrite).
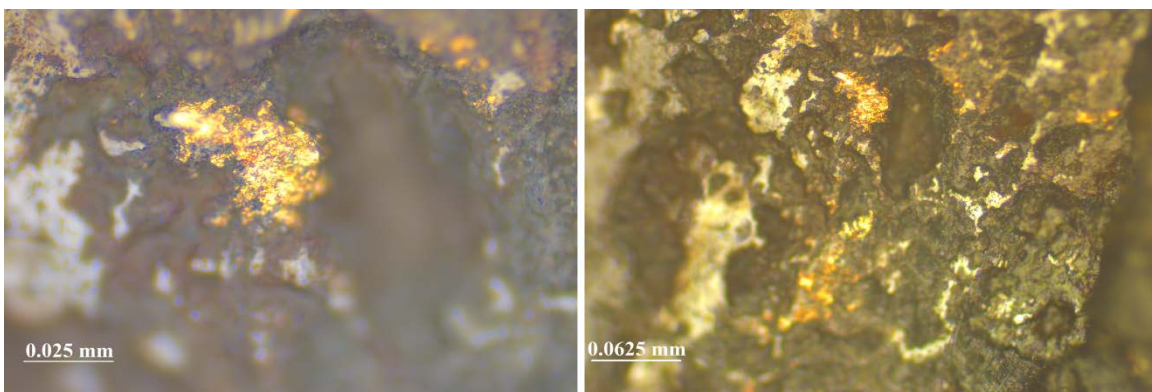

Figure 14. Photo micrograph showing gold observed under the metallographic microscope.

\subsection{Ore Geochemical Analysis}

The production of iron ore depends on several geochemical parameters including the total iron content and the contents of various noxious elements that form the gangue [20]. 


\subsubsection{Major Elements Composition and Determination of Total Iron Grade (Total Fe)}

The results of the geochemical analysis of the oolitic iron ore from the Kandi Basin are summarized in Table 1. The description of the collected samples as well as their spatial references and corresponding localities are mentioned in Table 2

The results indicate a high $\mathrm{Fe}_{2} \mathrm{O}_{3}$ content ranging from $57.91 \%$ to $89.39 \%$ followed by $\mathrm{SiO}_{2}$ and $\mathrm{Al}_{2} \mathrm{O}_{3}$ with contents ranging respectively from $5.8 \%$ to $33.19 \%$ and from $2.94 \%$ to $7.25 \%$ (Figures $15-18$ ).

For classification and quality assessment, iron ores were subdivided into three categories, based on the total iron content [21]. This classification is shown in Table 3.

- Determination of total iron grade (Total Fe)

In order to appreciate the economic potential of iron ore in the Kandi Basin for further exploration and exploitation, we compared the geochemical data of this study to those of ores in operation around the world.

To determine the total iron content, the main iron oxide $\left(\mathrm{Fe}_{2} \mathrm{O}_{3}\right)$ must be converted to the elemental state of iron (total iron). This conversion can be done in the following manner.

Weight of $\mathrm{Fe}=55.847 \mathrm{~g}$;

Weight of $\mathrm{O}=15.999 \mathrm{~g}$.

Molecular molar mass of $\mathrm{Fe}_{2} \mathrm{O}_{3}=2(55.847)+3(15.999)=159.69 \mathrm{~g} / \mathrm{mol}$

The proportion of total iron $=\frac{\mathrm{Fe}_{2}}{\mathrm{Fe}_{2} \mathrm{O}_{3}}$

$=2(55.847) / 159.69=111.694 / 159.69$

Total iron proportion $=0.699$

Total iron for each sample $=$ grade $\mathrm{Fe}_{2} \mathrm{O}_{3} \times$ total iron proportion

Table 1. Grades of various major elements of the Kandi Basin iron ore (Avg = Average; $\mathrm{Spl}=$ samples; $\mathrm{Cnt}=$ content $)$.

\begin{tabular}{cccccccccccc}
\hline Spl & A16 & A20 & B2 & B3 & B5 & B10 & B12 & D6' & D16 & D20 & Avg \\
\hline $\mathrm{SiO}_{2}$ & 5.8 & 8.94 & 11.22 & 22.37 & 3.07 & 6 & 5.7 & 10.67 & 13 & 33.19 & 11.99 \\
$\mathrm{TiO}_{2}$ & 0.05 & 0.03 & 0.02 & 0.13 & 0.05 & 0.05 & 0.03 & 0.18 & 0.57 & 0.5 & $\mathbf{0 . 1 6 1}$ \\
$\mathrm{Al}_{2} \mathrm{O}_{3}$ & 2.94 & 4.84 & 3.48 & 3.52 & 3.6 & 4.1 & 4.02 & 3.61 & 7.74 & 7.25 & 4.51 \\
$\mathrm{Fe}_{2} \mathrm{O}_{3}$ & 89.39 & 83.99 & 83.16 & 69.87 & 91.33 & 87.7 & 87.56 & 83.57 & 77.08 & 57.91 & $\mathbf{8 1 . 1 5}$ \\
$\mathrm{Fe} \mathrm{Total}$ & $\mathbf{6 2 . 4 8}$ & $\mathbf{5 8 . 7}$ & $\mathbf{5 8 . 1 2}$ & $\mathbf{4 8 . 8 3}$ & $\mathbf{6 3 . 8 3}$ & $\mathbf{6 1 . 3}$ & $\mathbf{6 1 . 2}$ & $\mathbf{5 8 . 4 1}$ & $\mathbf{5 3 . 8 7}$ & $\mathbf{4 0 . 4 7}$ & 56.72 \\
$\mathrm{MnO}$ & 0.18 & 0.34 & 0.05 & 0.04 & 0.08 & 0.05 & 0.05 & 0.21 & 0.17 & 0.13 & 0.13 \\
$\mathrm{MgO}$ & 0.02 & 0.08 & 0.04 & 0.69 & $<0.01$ & 0.01 & 0.02 & $<0.01$ & 0.02 & $<0.01$ & 0.14 \\
$\mathrm{CaO}$ & 0.16 & 0.17 & 0.07 & 1.59 & 0.05 & 0.05 & 0.2 & 0.06 & 0.11 & 0.13 & 0.259 \\
$\mathrm{Na}_{2} \mathrm{O}$ & $<0.01$ & $<0.01$ & $<0.01$ & $<0.01$ & $<0.01$ & $<0.01$ & $<0.01$ & $<0.01$ & 0.01 & $<0.01$ & 0.01 \\
$\mathrm{~K}_{2} \mathrm{O}$ & $<0.01$ & 0.01 & $<0.01$ & 0.59 & $<0.01$ & $<0.01$ & 0.01 & $<0.01$ & 0.02 & 0.02 & 0.065 \\
$\mathrm{P}_{2} \mathrm{O}_{5}$ & 1.35 & 1.41 & 1.75 & 1.05 & 1.70 & 1.90 & 2.29 & 1.58 & 1.11 & 0.79 & 1.49 \\
$\mathrm{Cr}_{2} \mathrm{O}_{3}$ & 0.03 & 0.02 & 0.03 & 0.02 & 0.03 & 0.03 & 0.02 & 0.02 & 0.03 & 0.02 & 0.025 \\
$\mathrm{~V}_{2} \mathrm{O}_{5}$ & 0.05 & 0.05 & 0.11 & 0.06 & 0.05 & 0.05 & 0.04 & 0.06 & 0.08 & 0.04 & 0.059 \\
$\mathrm{SO}_{3}$ & $<0.3$ & $<0.3$ & $<0.3$ & $<0.3$ & $<0.3$ & $<0.3$ & $<0.3$ & $<0.3$ & $<0.3$ & $<0.3$ & $<0.3$ \\
\hline & & & & & & & & & & & \\
\hline
\end{tabular}


Table 2. Description of collected samples with localities and spatial references.

\begin{tabular}{|c|c|c|c|c|}
\hline Samples & Easting (E) & Northing $(\mathrm{N})$ & Description & Location \\
\hline A16 & 534599 & 1307216 & $\begin{array}{l}\text { Reddish oolitic iron ore, } \\
\text { with spherical ooïds }\end{array}$ & Madékali \\
\hline $\mathrm{A} 20$ & 544933 & 1296552 & $\begin{array}{l}\text { Dark red oolitic iron ore } \\
\text { with yellowish stains }\end{array}$ & Madékali \\
\hline B2 & 553305 & 1284132 & Dense oolitic iron ore & Sendé \\
\hline B3 & 538719 & 1277156 & $\begin{array}{l}\text { Indurated scoria, very } \\
\text { ferrugineous and dense }\end{array}$ & Sendé \\
\hline B5 & 539474 & 1278511 & Dense oolitic iron ore & Sendé \\
\hline $\mathrm{B} 10$ & 554688 & 1281944 & Dense and shiny oolitic iron ore & Sendé \\
\hline B12 & 553336 & 1286453 & Dense and shiny oolitic iron ore & Sendé \\
\hline D6 & 518200 & 1303077 & Dense and shiny oolitic iron ore & Guéné - Goungoun \\
\hline D16 & 517265 & 1277734 & $\begin{array}{c}\text { Laterite with ferrugineous } \\
\text { oolite, dense }\end{array}$ & Guéné - Goungoun \\
\hline $\mathrm{D} 20$ & 521646 & 1246402 & $\begin{array}{c}\text { Variegated ferrugineous lateritic } \\
\text { sandstone (reddish, yellowish), } \\
\text { oolitic and dense }\end{array}$ & Fouè \\
\hline
\end{tabular}

Table 3. Generalized percentages of elements of major interest in assessing iron ore quality [3].

\begin{tabular}{|c|c|c|c|c|c|c|c|}
\hline Components & & total Fe & & $\mathrm{SiO}_{2}$ & $\mathrm{Al}_{2} \mathrm{O}_{3}$ & Phosphorous & Sulphur \\
\hline \multirow{2}{*}{ Contents } & Low (L) & Medium (M) & $\operatorname{High}(\mathrm{H})$ & \multirow{2}{*}{$<6 \%$} & \multirow{2}{*}{$3 \%-4 \%$} & \multirow{2}{*}{$0.05 \%-0.07 \%$} & \multirow{2}{*}{$0.1 \%$} \\
\hline & $<58 \%$ & $62 \%-64 \%$ & $>65 \%$ & & & & \\
\hline
\end{tabular}

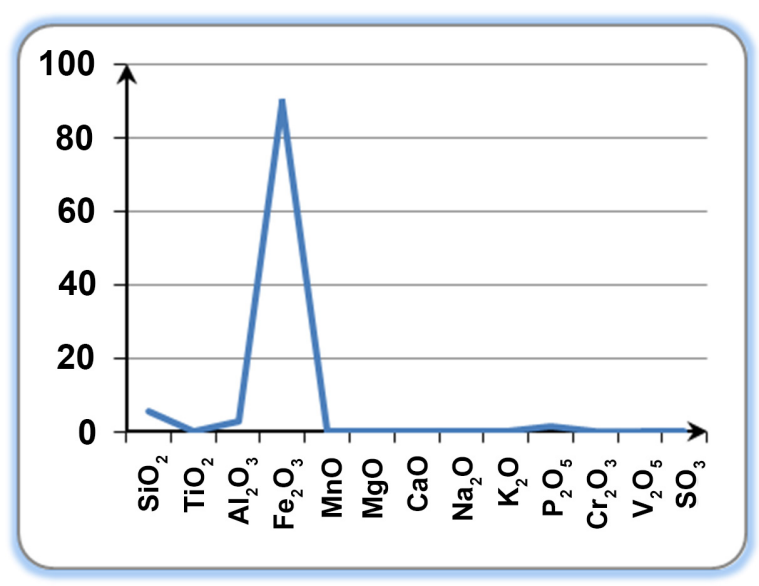

Figure 15. Distribution patterns of the geochemical elements (sample A16).

\subsubsection{Relationship between Iron and Other Major Elements: Regression Analysis and "Fitted Line Plot"}

This study is done in order to understand the type of relationship between iron and other existing elements in the ore. This analysis generates an equation that describe the statistical relationship between one or more predictors $\left(\mathrm{Fe}_{2} \mathrm{O}_{3}\right)$ and the response variable $\left(\mathrm{SiO}_{2}, \mathrm{P}_{2} \mathrm{O}_{5}, \mathrm{SO}_{3}, \mathrm{~V}_{2} \mathrm{O}_{5}, \mathrm{TiO}_{2}, \mathrm{MnO}, \mathrm{MgO}, \mathrm{Al}_{2} \mathrm{O}_{3}, \mathrm{CaO}\right.$, 


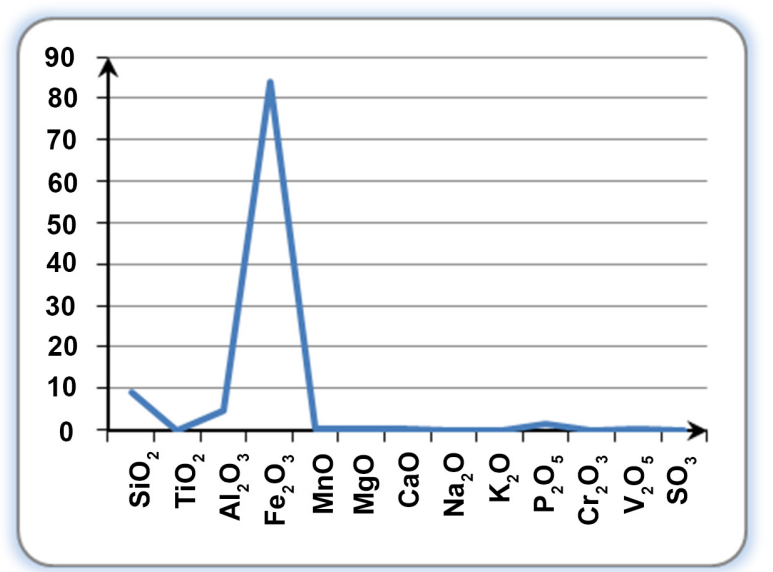

Figure 16. Distribution patterns of the geochemical elements (sample B3).

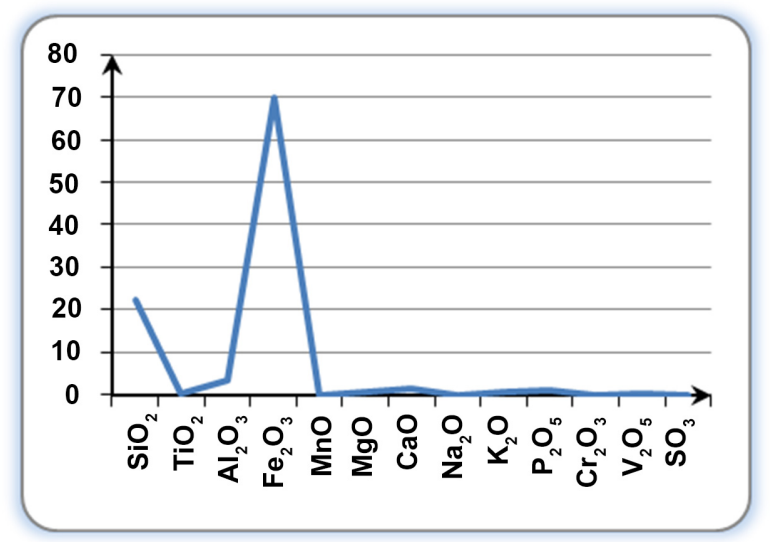

Figure 17. Distribution patterns of the geochemical elements (sample A20).

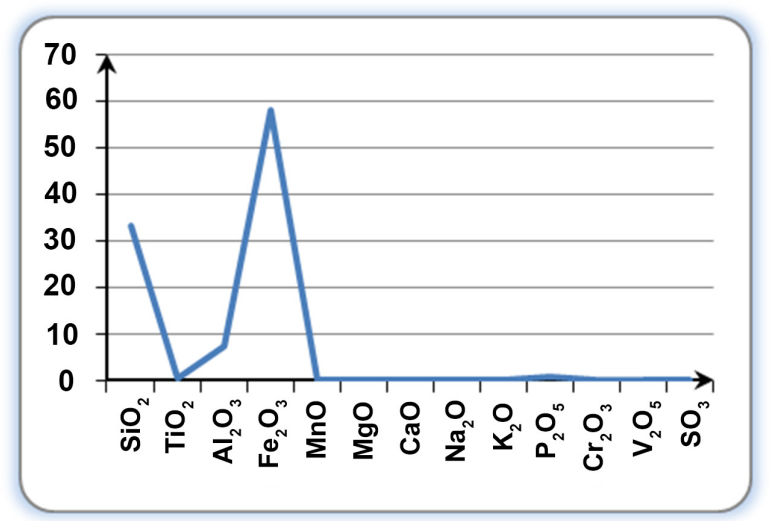

Figure 18. Distribution patterns of the geochemical elements (sample D20).

$\mathrm{Na}_{2} \mathrm{O}, \mathrm{K}_{2} \mathrm{O}$ and $\mathrm{Cr}_{2} \mathrm{O}_{3}$ ) [22]. The regression results provide information on the direction, size, and statistical significance of the relationship between the 
predictor $\left(\mathrm{Fe}_{2} \mathrm{O}_{3}\right)$ and the response (the other oxides). Each coefficient indicates the trend of the relationships between the elements. Moreover, the "fitted line plot" allows us to know the type of relation between two continuous variables: the predictor and the response. Once the "fitted line plot" is created, the response variable is displayed on the $y$-axis $(y)$ and the predictor variable on the $\mathrm{x}$-axis. This statistical analysis was carried out with the Minitab 14 statistical software that allows to predict the type of relationship between the main oxide of interest $\left(\mathrm{Fe}_{2} \mathrm{O}_{3}\right)$ and the other oxides $\left(\mathrm{SiO}_{2}, \mathrm{P}_{2} \mathrm{O}_{5}, \mathrm{SO}_{3}, \mathrm{~V}_{2} \mathrm{O}_{5}, \mathrm{TiO}_{2}, \mathrm{MnO}, \mathrm{MgO}\right.$, $\mathrm{Al}_{2} \mathrm{O}_{3}, \mathrm{CaO}, \mathrm{Na}_{2} \mathrm{O}, \mathrm{K} 2 \mathrm{O}$ and $\mathrm{Cr}_{2} \mathrm{O}_{3}$ ).

In the Minitab software, $\mathrm{S}=$ standard deviation of the error; $\mathrm{R}^{2}(\mathrm{R}-\mathrm{Sq})=$ coefficient of determination.

From these results, we observed that $\mathrm{SiO}_{2}, \mathrm{TiO}_{2}, \mathrm{Al}_{2} \mathrm{O}_{3}, \mathrm{MgO}, \mathrm{CaO}, \mathrm{Na}_{2} \mathrm{O}$ and $\mathrm{K}_{2} \mathrm{O}$ have an inverse relationship with $\mathrm{Fe}_{2} \mathrm{O}_{3}$ with a degree of response corresponding respectively to $98.6 \%, 50.2 \%, 39.9 \%, 13.9 \%, 15 \%, 7.9 \%$, and 16.4\%. Silica thus has a strong correlation and is closely related to iron. This kind of relationship is smilar to that of Koton Karfe oolitic in northern part of Nigeria [2]. On the other hand, $\mathrm{MnO}, \mathrm{P}_{2} \mathrm{O}_{5}, \mathrm{Cr}_{2} \mathrm{O}_{3}, \mathrm{~V}_{2} \mathrm{O}_{5}$ and $\mathrm{SO}_{3}$ have a direct relationship with $\mathrm{Fe}_{2} \mathrm{O}_{3}$ with a degree of variation response of $0.1 \%, 60 \%, 0 \%$ and $0.2 \%$ respectively. Phosphorus thus has a strong correlation and is intimately related to iron, whereas sulfur is weakly associated to it (Figures 19-30).

Analysis of the atomic absorption spectrometry reveals gold occurence in the ferrugineous sandstones of the Continental Terminal Formation (Table 4). We can see that the gold occurence ( $0.015 \mathrm{ppm}$ in average) is three times higher than its crustal clarke (0.005 ppm).

\section{Discussion}

The most important elements and compounds to take into account in the study of iron ore are: total iron ( $\mathrm{Fe}$ ), gangue mainly composed of $\mathrm{SiO}_{2}$ and $\mathrm{Al}_{2} \mathrm{O}_{3}$ and noxious elements (phosphorus and sulfur). In addition to these elements, the iron ore contains other accessory oxides such as $\mathrm{MnO}, \mathrm{MgO}, \mathrm{TiO}$ and $\mathrm{CaO}$ but

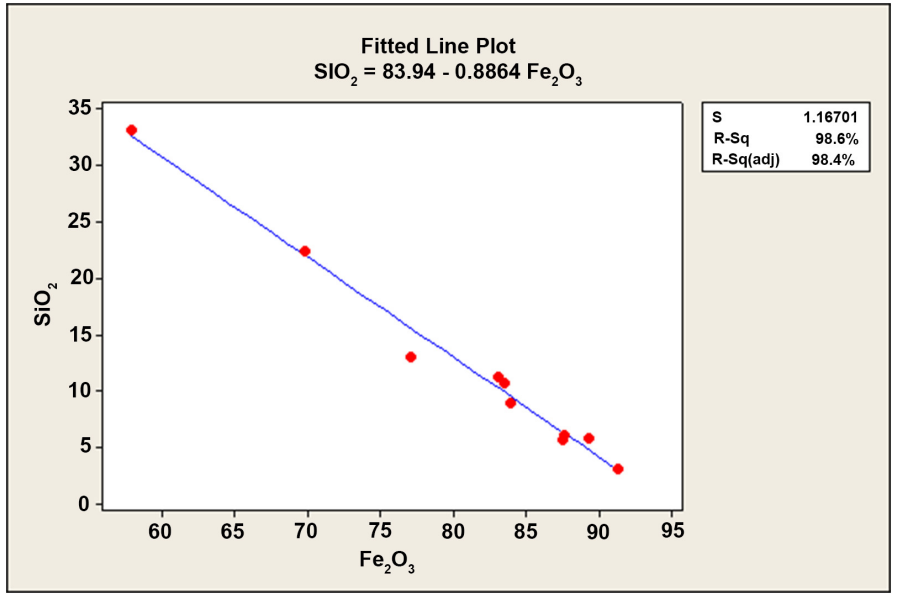

Figure 19. Regression analysis with fitted line: $\mathrm{SiO}_{2}$ versus $\mathrm{Fe}_{2} \mathrm{O}_{3}$. 


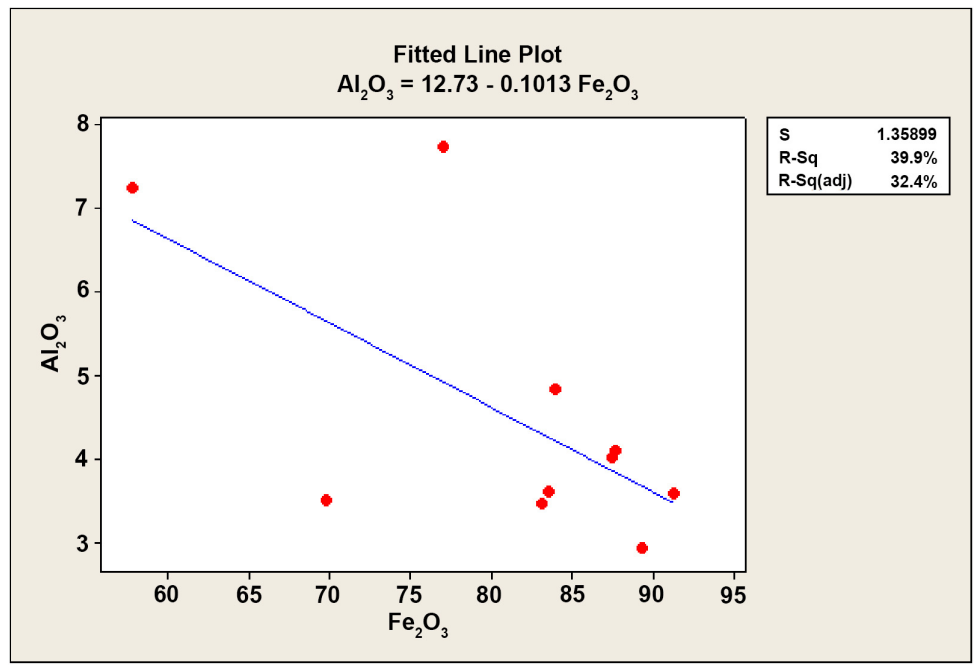

Figure 20. Regression analysis with fitted line: $\mathrm{Al}_{2} \mathrm{O}_{3}$ versus $\mathrm{Fe}_{2} \mathrm{O}_{3}$.

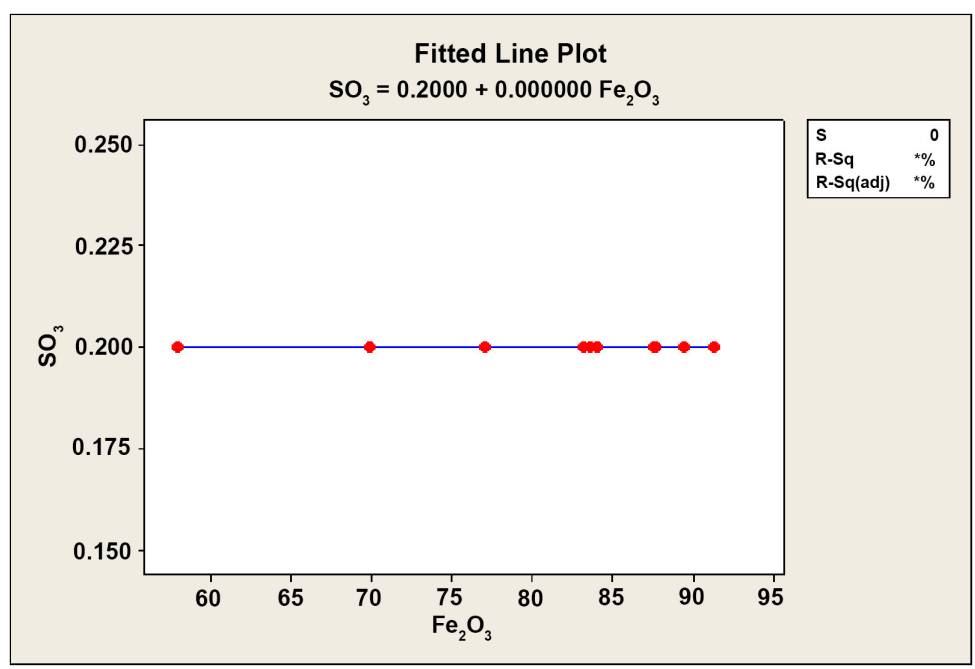

Figure 21. Regression analysis with fitted line: $\mathrm{SO}_{3}$ versus $\mathrm{Fe}_{2} \mathrm{O}_{3}$.

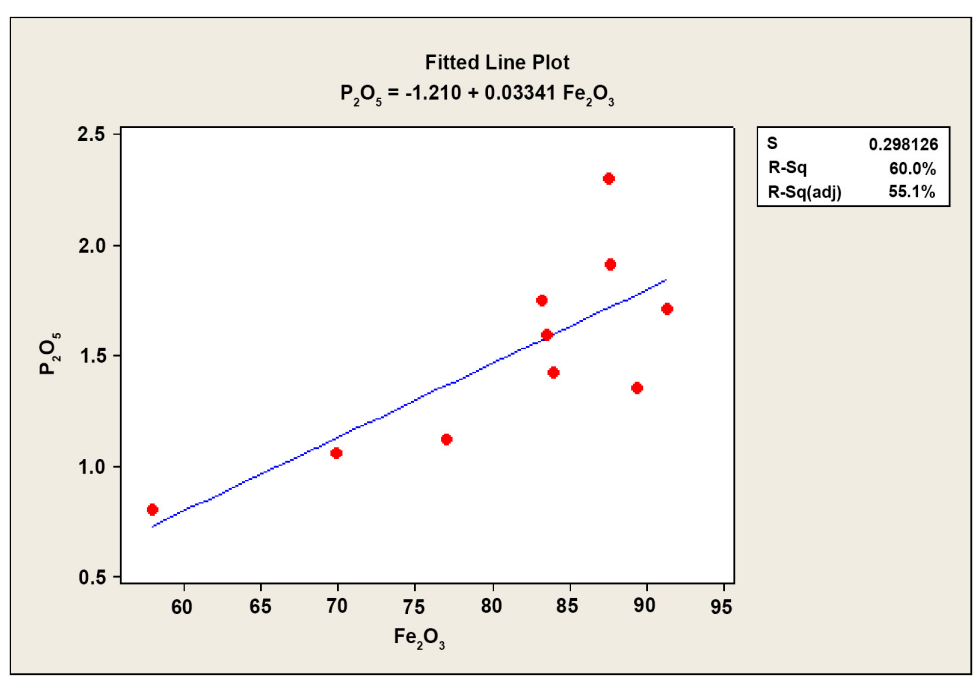

Figure 22. Regression analysis with fitted line: $\mathrm{P}_{2} \mathrm{O}_{5}$ versus $\mathrm{Fe}_{2} \mathrm{O}_{3}$. 


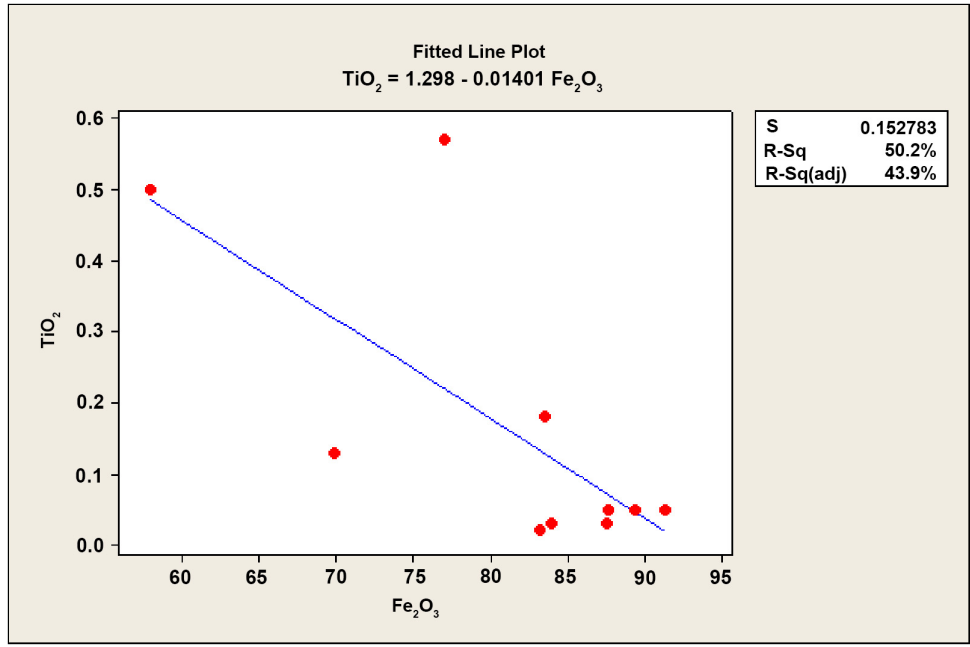

Figure 23. Regression analysis with fitted line: $\mathrm{TiO}_{2}$ versus $\mathrm{Fe}_{2} \mathrm{O}_{3}$.

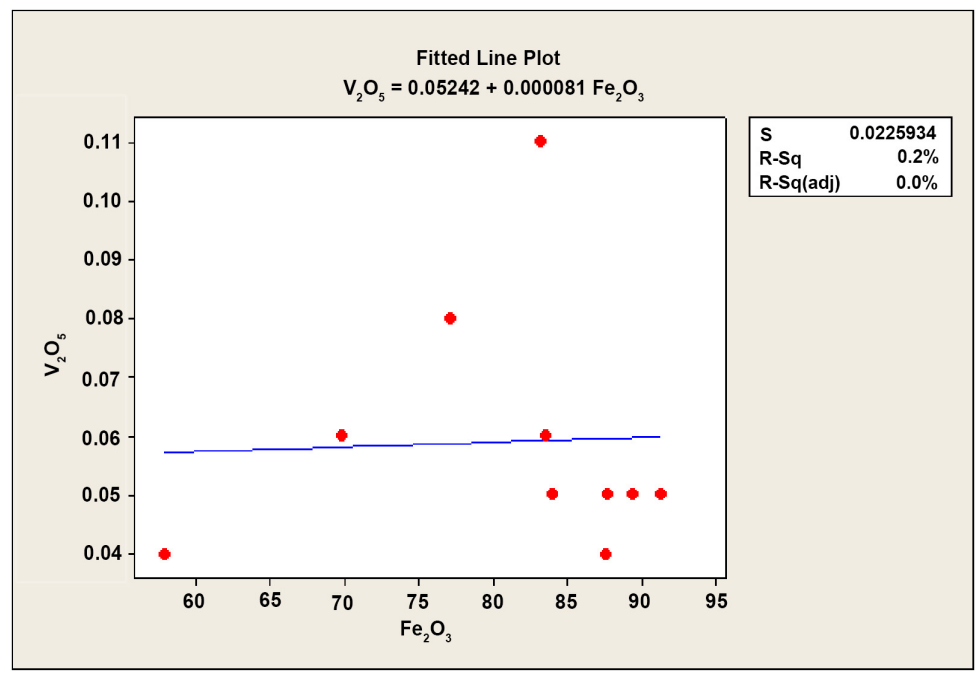

Figure 24. Regression analysis with fitted line: $\mathrm{V}_{2} \mathrm{O}_{5}$ versus $\mathrm{Fe}_{2} \mathrm{O}_{3}$.

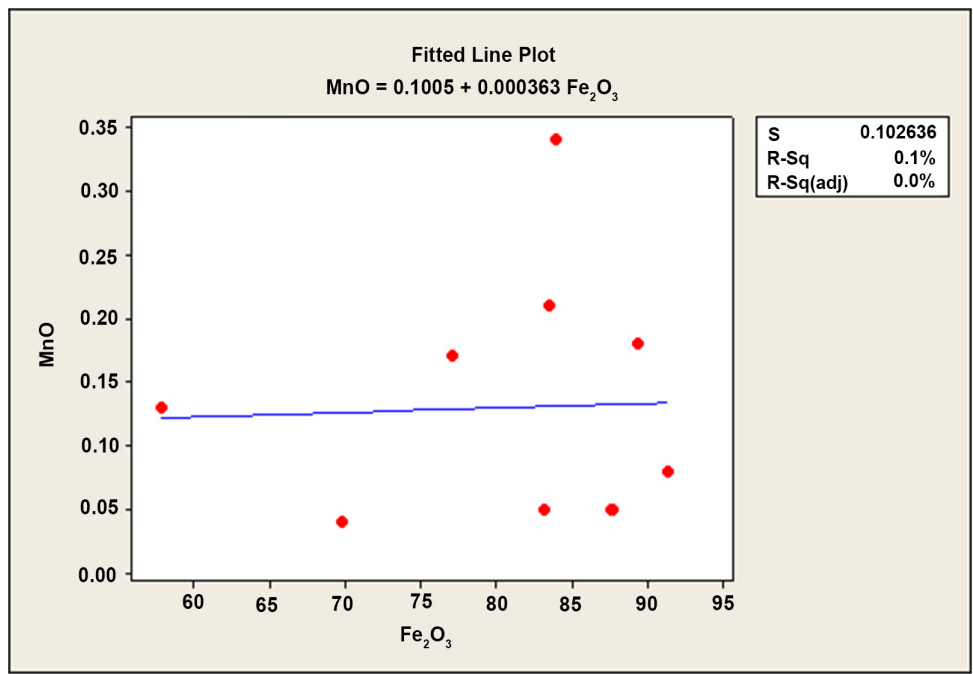

Figure 25. Regression analysis with fitted line: $\mathrm{MnO}$ versus $\mathrm{Fe}_{2} \mathrm{O}_{3}$. 


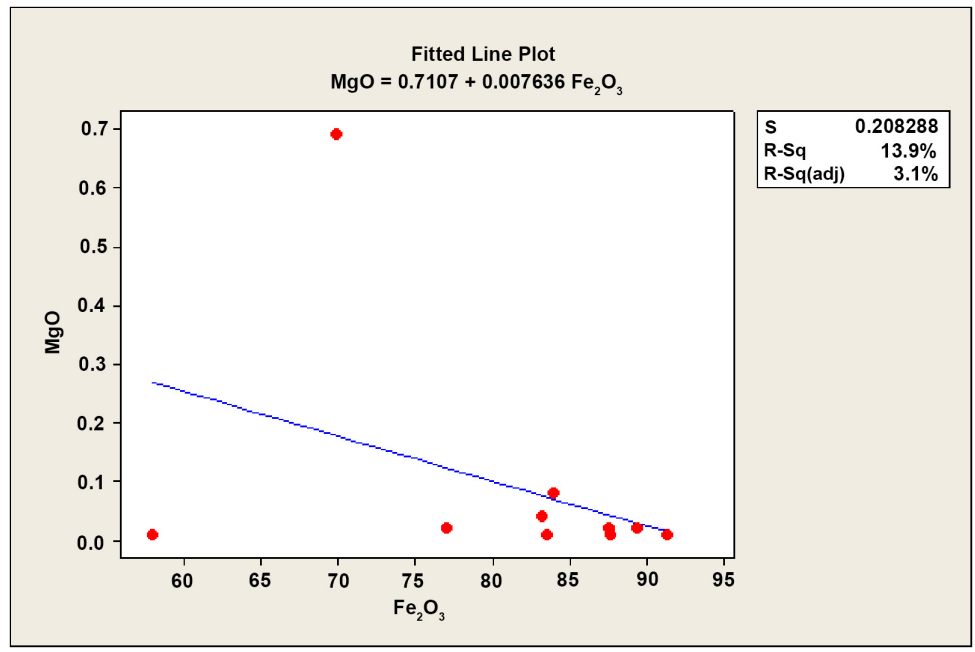

Figure 26. Regression analysis with fitted line: $\mathrm{M}_{\mathrm{g}} \mathrm{O}$ versus $\mathrm{Fe}_{2} \mathrm{O}_{3}$.

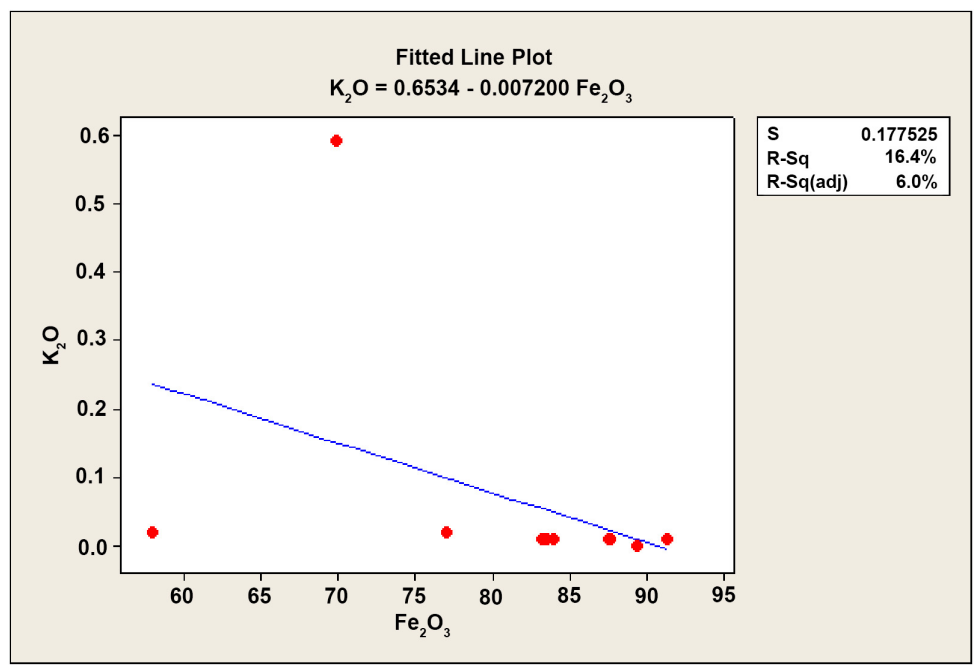

Figure 27. Regression analysis with fitted line: $\mathrm{K}_{2} \mathrm{O}$ versus $\mathrm{Fe}_{2} \mathrm{O}_{3}$.

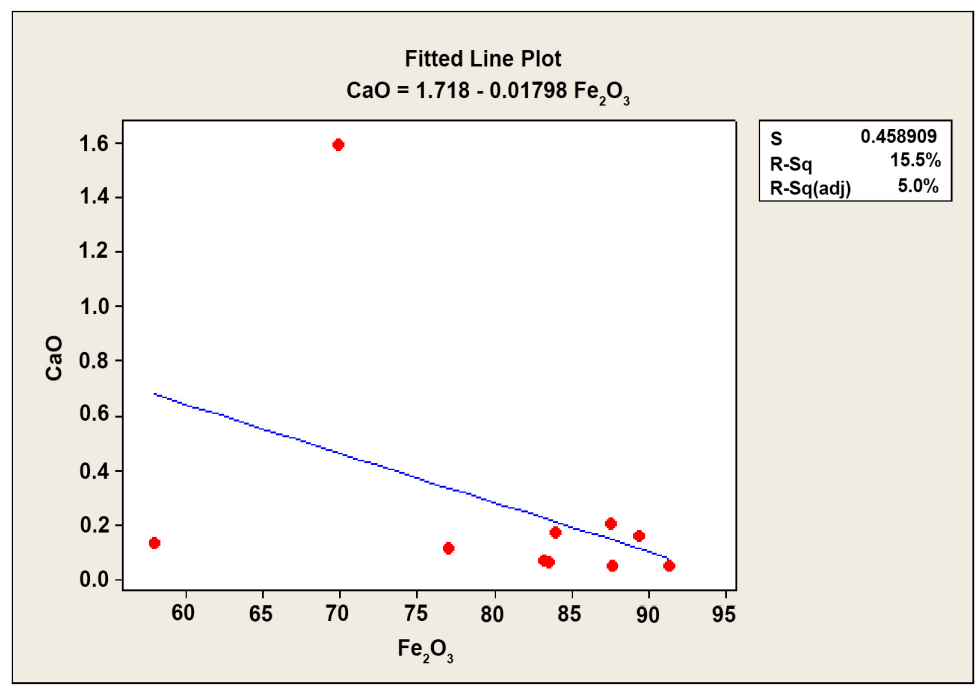

Figure 28. Regression analysis with fitted line: $\mathrm{CaO}$ versus $\mathrm{Fe}_{2} \mathrm{O}_{3}$. 


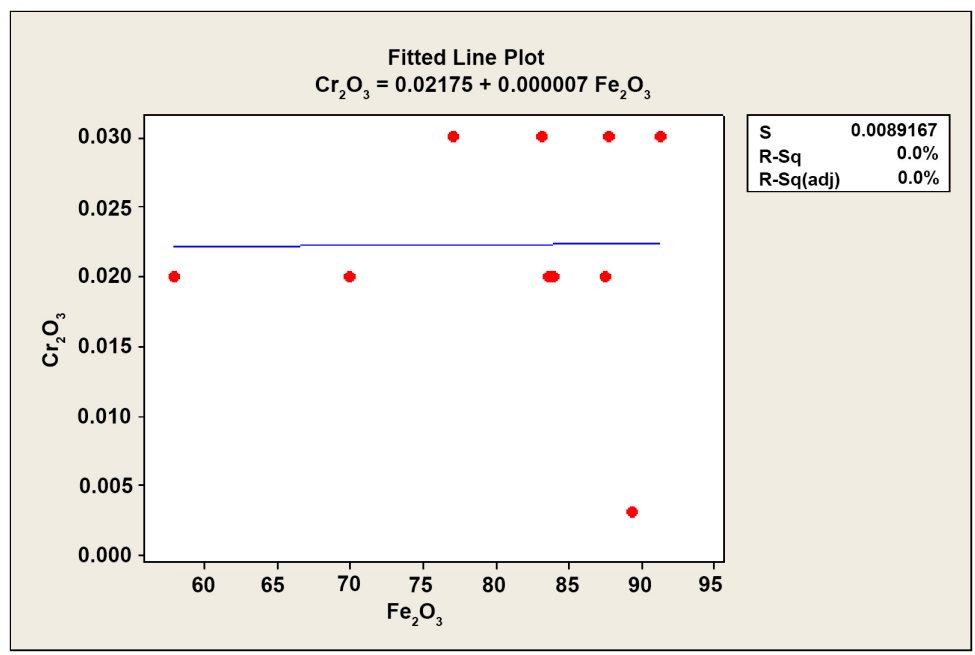

Figure 29. Regression analysis with fitted line: $\mathrm{Cr}_{2} \mathrm{O}_{3}$ versus $\mathrm{Fe}_{2} \mathrm{O}_{3}$.

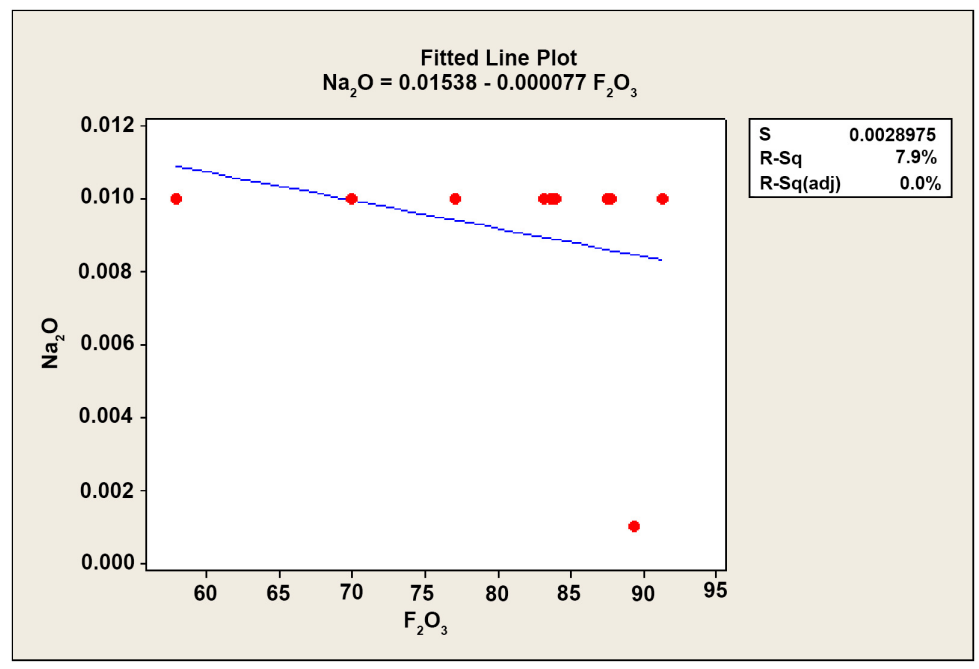

Figure 30. Regression analysis with fitted line : $\mathrm{Na}_{2} \mathrm{O}$ versus $\mathrm{Fe}_{2} \mathrm{O}_{3}$.

in negligible quantities [2]. Phosphorus, aluminum and sulfur are considered as impurities in the steel manufacture process. Their presence in large quantities is an obstacle to the exploitation of iron ore.

For commercial viability, iron ores must have a high total iron content and a very low content of noxious elements.

In the oolitic iron ore of the Kandi Basin, silicon and aluminum are present in significant proportion ( $11.99 \%$ for silicon and $4.51 \%$ for aluminum). They are not chemically related to iron but seem to be intimately associated to it. This promotes easy separation of these elements. On the other hand, sulfur and phosphorus are chemically associated to iron but with a weak correlation. The close relation between iron and vanadium ensures agood alloying, a hardness and a strength [21].

For a better mining, the average of the total iron content of an iron ore must be between $30 \%$ and $65 \%$ [23]. Geochemical analyzes have shown that iron ore 
Table 4. Results of gold's geochemical analysis (Atomic Absorption Spectrometry).

\begin{tabular}{cc}
\hline Samples & Gold's grades (ppm) \\
M1-Ma-Be-18 & 0.015 \\
M2-Ma-Be-18 & 0.006 \\
M3-Ma-Be-18 & $<0.005$ \\
M4-Ma-Be-18 & $<0.005$ \\
M5-Ma-Be-18 & $<0.005$ \\
M6-Ma-Be-18 & $<0.005$ \\
M7-Ma-Be-18 & $<0.005$ \\
M8-Ma-Be-18 & $<0.005$ \\
M9-Ma-Be-18 & $<0.005$ \\
M10-Ma-Be-18 & $<0.005$ \\
\hline
\end{tabular}

in the Kandi Basin has total iron contents between $40.47 \%$ and $63.88 \%$ with an average grade of $56.72 \%$. According to [21] classification (Table 3), the iron ore in Kandi Basin is classified in the C category, ie, low grade ores. The silicon levels, ranging from $5.8 \%$ to $33.19 \%$ with an average of $11.99 \%$, are considered to be above the required limit in metallurgy [21]. On the other hand, the phosphorus contents varying from $1.06 \%$ to $2.3 \%$ and those of sulfur below $0.3 \%$ are also considered unacceptable for steel production [21].

Based on these results, iron ore from the Kandi Basin could not be used for steel production but presents favorable characteristics for the production of cast iron. In contrast to the manufacture of steel, the high silicon content would be an asset for cast iron production [24]. Indeed, this high silicon content reduces the shrinkage of the cast iron and reduces the strength of the steel [25]. Although being in low proportion (contents lower than $0.7 \%$ ), the phosphorus weakens the steel. The strength and hardness of steel decrease with increasing phosphorus content [26]. In the iron ore of the Kandi Basin, the phosphorus content varies from $0.8 \%$ to $2.3 \%$, which is significantly higher than the accepted metallurgical content $(0.05 \%-0.07 \%)$.

Aluminum oxide increases the viscosity of iron ore during the steel production process. In iron ore from the Kandi Basin, aluminum oxide contents range from $2.94 \%$ to $7.74 \%$. This content is also higher than the accepted proportion $(3 \%-4 \%)$.

According to [24], the sulfur content tolerated in iron ore must be less than $0.15 \%$. As for [23], this sulfur content must not be greater than $0.2 \%$. According to [26], the presence in small amounts of sulfur is considered to be an unfavorable parameter for the production of steel and cast iron. The presence or the lack of sulfur is therefore an important indicator for investors [27].

The presence of vanadium in an iron ore is an asset for the production of steel. Even if the vanadium contents is less than $0.2 \%$, it allows the production of the steel with good hardness and a good mechanical strength. In the iron ore of 
Table 5. Complete chemical composition of iron ore from different nations [12].

\begin{tabular}{|c|c|c|c|c|c|c|c|}
\hline \multirow{2}{*}{ Mine } & \multirow{2}{*}{ Countries } & \multicolumn{5}{|c|}{ Chemical composition (\%) } & \multirow{2}{*}{ Ore grade } \\
\hline & & $\mathrm{Fe}_{\text {total }}$ & $\mathrm{SiO}_{2}$ & $\mathrm{Al}_{2} \mathrm{O}_{3}$ & $S$ & $\mathbf{P}$ & \\
\hline Itabira & Brazil & 68.9 & 0.35 & 0.60 & 0.010 & 0.030 & High \\
\hline MBR & Brazil & 67.3 & 0.79 & 0.72 & 0.005 & 0.037 & High \\
\hline Carajas & Brazil & 65.4 & 1.00 & 1.05 & 0.010 & 0.038 & High \\
\hline Nanfen & China & 63.4 & 6.28 & 1.17 & 0.110 & - & Middle \\
\hline Goldsworthy & Australia & 63.2 & 4.90 & 1.60 & - & 0.035 & Middle \\
\hline Hammersley & Australia & 62.7 & 4.20 & 2.73 & 0.016 & 0.059 & Middle \\
\hline Irvine Island & Australia & 54.4 & 21.3 & 0.23 & 0.040 & 0.010 & Low \\
\hline Goa & India & 57.8 & 2.50 & 6.50 & 0.020 & 0.040 & Low \\
\hline Donimalai & India & 63.5 & 3.00 & 3.00 & 0.050 & 0.080 & Middle \\
\hline Bailadila & India & 64.0 & 2.50 & 2.50 & 0.050 & 0.100 & Middle \\
\hline Bakal & Russia & 60.7 & 2.40 & 2.00 & 0.030 & 0.004 & Middle \\
\hline Tula & Russia & 52.2 & 10.10 & 1.25 & 0.100 & 0.600 & Low \\
\hline Mesabi & USA & 57.5 & 10.10 & 0.70 & 0.010 & 0.060 & Low \\
\hline Minnesota & USA & 54.3 & 6.80 & 0.40 & - & 0.230 & Low \\
\hline Reserve Pellet & USA & 63.0 & 8.10 & 0.40 & 0.003 & 0.025 & Middle \\
\hline Rushekye & Uganda & 68.4 & 0.96 & 0.58 & $<0.001$ & $<0.02$ & High \\
\hline Kamena & Uganda & 67.9 & 0.80 & 0.65 & 0.002 & 0.02 & High \\
\hline Kyanyamuzinda & Uganda & 68.7 & 0.41 & 0.35 & 0.006 & 0.02 & High \\
\hline $\begin{array}{l}\text { Oolitic iron ore } \\
\text { of Kandi Basin }\end{array}$ & Benin & 56.72 & 11.99 & 4.51 & $<0.3$ & 0.65 & $\begin{array}{c}\text { Low } \\
\text { (present } \\
\text { work) }\end{array}$ \\
\hline
\end{tabular}

the Kandi Basin, the vanadium content which ranges between $0.04 \%$ and $0.11 \%$ represents a good indicator for the production of the alloy of high quality.

- Quality comparison between Kandi Basin oolitic iron ore and other mined iron ores around the world

Before developing any deposit, it is necessary to compare it to those already in operation in several regions of the world. For intance, we have compared the geochemical characteristics of Kandi Basin iron ore with those of Brazil, China, Australia, India, Russia, United States, and Uganda (Table 5).

Although the iron ore in the Kandi Basin is classified among the low grade ores, according to the [21] classification, the Kandi Basin total iron content is higher than that of the Tula deposit in Russia (Table 5). We could also noted that the silica and alumina contents are respectively lower than those of the deposits in operation in Australia and India (Table 5). Despite the slightly higher sulfur and phosphorus contents, the iron ore of the Kandi Basin can be promoted for detailed exploration.

\section{Conclusion}

The iron ore in the Kandi Basin contains mainly quartz, goethite, hematite and 
magnetite. Incidentally, it contains pyrite, chalcopyrite, blende, galena, gold, zircon and scheelite. Noxious elements such as sulfur and phosphorus have contents above the allowed limit in metallurgy. However, because of the acceptable vanadium content $(0.059 \%)$, this iron ore has favorable characteristics for the production of cast iron. Besides, further investigations must be carried out to clarify the sulfur content; because a higher sulfur grades may negatively impact the strength of the cast iron and the steel.

Compared to other iron deposits in operation, the iron ore in the Kandi Basin has favorable geochemical characteristics for mining.

\section{Conflicts of Interest}

The authors declare no conflicts of interest regarding the publication of this paper.

\section{References}

[1] Jebrak, M. and Marcoux, E. (2008) Geology of Mineral Resources. Geology of Quebec, 667 p.

[2] Imrana, A. and Haruna, V. (2017) Geology, Mineralogy and Geochemistry of Koton-karfe Oolitic Iron Ore Deposit, Bida Basin. Kogi State, Nigeria. International Journal of Scientific \& Technology Research, 6, 415-426.

[3] Dreesen, R., Goemaere, E., Katsch, A., Eschgi, I., Savary, X. and Dupret, L. (1989) Geological Record and Sedimentology of the Paleozoic Oolitic Ironstone Deposit in the Western Europe. Spatial Relationships with the Linienbandkeramik Settlement (LBK) in Belgium. Geological Society, Special Publication, No. 46, 9-25.

[4] Allerton, S. (1914) Modern Research in the Metallurgy of Iron. Scientific American Supplement, No. 2025, 258-313.

[5] Well, M., Ramanaidou, E. and McGregor, F. (2010) Phanerozoic Ooidal Ironstone Deposits-Generation of Potential Exploration Target. Applied Earth Science, 119, 60-64.

[6] Goemaere, E., Katcch, A., Eschghi, I. and Dreesen, R. (2016) Geological Record and Depositional Setting of Palaeozoic Oolitic Ironstone in Western Europa. Anthropological et Praehistorica, 125, 23-43.

[7] Franklyn, B. and Van Houten (1992) Revew of Cenozoic Ooidal Ironstone. Sedimentary Geology, 78, 101-110.

[8] Kogbé, C. and Dubois, D. (1980) Economic Significance of the Continental Terminal (CT). IGCP Project 127 on the Concept of the Continental Terminal in Africa, Band 69, Heftz 2, 429-436.

[9] Conrad, G. and Lappartient, J.-R. (1987) The Continental Terminal, Its Place in Geodynamic Evolution of Senegalo-Mauritanian Basin during the Cenozoic Time. Journal of African Earth Sciences, 6, 45-60.

[10] Issifou, F. (2015) Ferriferous Mineralisation of Madekali: Mapping, Petrographical, Physical and Chemical Characterization and Tonnage Assessment. Master's Thesis, University of Abomey, Calavi, 85 p.

[11] Sifré, T. (1961) Profitable Industrial Concentration Survey of Kandi Iron Ore Deposit. Mission Report, Mines and Geologyservice, Cotonou.

[12] Hubert, H. (1908) Scientific Mission in Dahomey, Iris, lilliad, Université Lille 1. 628 
p.

[13] Dominique, C., Grimaud, J.-L., Beauvais, A. and Bamba, O. (2018) West African Lateritic Pediments: Landform-Regolith Evolution Processes and Mineral Exploration Pitfalls. Elsevier, Earth-Science Reviews, 124-146.

[14] Alidou, S. (1983) Geological Survey of Kandi Paleo-Mesozoicbasin. PhD Thesis, University of Dijon, $328 \mathrm{p}$.

[15] Lang, J., Kogbé, C., Alidou, S., Alzouma, K., Dubois, D., Houessou, A. and Trichet, J. (1986) The Siderolithic of the West African Tertiary and the Concept of the Continental Terminal. Bulletin de la Société géologique de France, 2, 605-622.

[16] Kogbé, C. (1978) Origine and Composition of the Ferruginuous Oolites and Laterite of North-Western Nigeria. Paper Presented at the Colloquium on African Geology, Geological Institute. Band 67, 662-674.

[17] Konaté, M. (1996) Tectono-Sedimentary Evolution of Kandi Paleozoic Basin (North Benin-South Niger)-A Witness of Post-Orogenic Extension of the Pan African Range. PhD Thesis, University of Bourgogne, Vol. 1, 290 p.

[18] Konaté, M., Lang, J., Guiraud, M., Yahaya, M., Denis, M. and Alidou, S. (2006) An Extensive Basin Formed during the Melting of the Hirnantian Ice Cap: The Ordovico-Silurian Basin of Kandi (North Benin, South Niger). Africa Geoscience Review, 13, 157-183.

[19] Konaté, M., Guiraud, M., Lang, J. and Yahaya, M. (2003) Sedimentation in the Kandi Extensional Basin (Benin and Niger): Fluvial and Marine Deposits Related to the Late Ordovician Deglaciation in West Africa. Journal African Earth Sciences, 36, 185-206. https://doi.org/10.1016/S0899-5362(03)00026-5

[20] Yuan, D., Wu, S., Guoliang, Z., Fangyi, L. and Juan, Z. (2012) The Influence of Iron Ore Quality Degradation on the Assimilability of Sinter Ore. Advanced Materials Research, 391-392, 71-74.

[21] Dobbins, M.S. and Burnet, G. (1982) Production of an Iron Ore Concentrates from the Iron-Rich Fraction of Power Plant Fly Ash. Resources and Conservation, 9, 231-242. https://doi.org/10.1016/0166-3097(82)90078-5

[22] Van Belle, F. and Claustriaux, J. (1995) Introduction to Data Analysis by Minitab Software. $15 \mathrm{p}$.

[23] Dill, G.H. (2008) The Chessboard Classification Scheme of Mineral Deposits: Mineralogy and Geology from Aluminum to Zirconium. Elsevier, Earth-Science Reviews, Amsterdam, 420p. http://www.elsevier.com/locate/earscirev

[24] Turner, T. (1900) The Metallurgy of Iron. 2nd Edition, Charles Griffin \& Company, Limited.

[25] Lyon, D. (1914) Some Metallurgical Problems. Problems Connected with the Metallurgy of Iron and Steel. Economic Geology, 6, 670.

[26] Gordon, R.B. (1996) American Iron 1607-1900. The John's Hopkins University Press.

[27] Agunleti, S. and Salau, S. (2015) Geochemical Studies and Exploration Potential of the Oolitic-Pisolitic Ironstone Deposit of Agbadja Formation (Southern Bida Basin, North Central Nigeria). International Journal of Innovative Science, Engineering and Technology, 2, 527-533.

[28] Institut De Recherche Breda (1989) Explanatory Note of the Geological Map (1/200 000): Sheet of Kandi and Malanville. Memory No. 2, Benin Office of Mines, Cotonou, $75 \mathrm{p}$. 